Tjalling C. Koopmans Research Institute Thlligh Aoopman

Discussion Paper Series nr: 13-07

\title{
Importing, productivity and SMEs: firm-level evidence from the Netherlands
}

M arcel van den Berg 


\section{Tjalling C. Koopmans Research Institute Utrecht School of Economics \\ Utrecht University}

Kriekenpitplein 21-22

3584 EC Utrecht

The Netherlands

telephone +31302539800

fax +31302537373

website www.koopmansinstitute.uu.nl

The Tjalling C. Koopmans Institute is the research institute and research school of Utrecht School of Economics.

It was founded in 2003, and named after Professor Tjalling C. Koopmans, Dutch-born Nobel Prize laureate in economics of 1975.

In the discussion papers series the Koopmans Institute publishes results of ongoing research for early dissemination of research results, and to enhance discussion with colleagues.

Please send any comments and suggestions on the Koopmans institute, or this series to J.M.vanDort@uu.nl

ontwerp voorblad: WRIK Utrecht

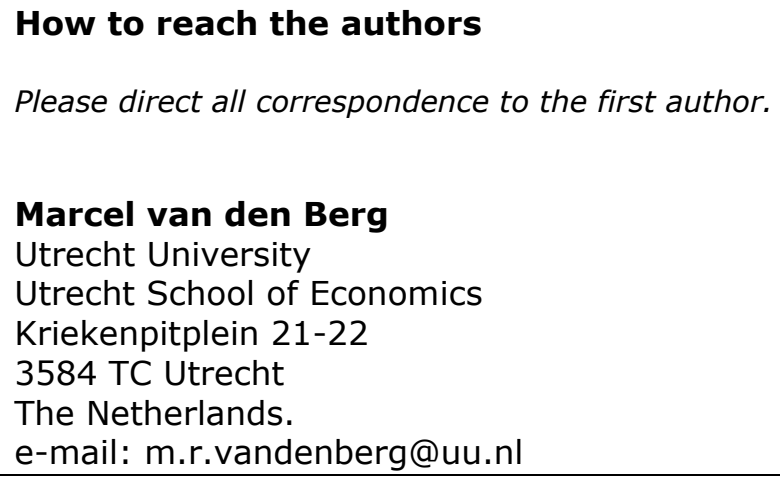

This paper can be downloaded at: http:// www.uu.nl/rebo/economie/discussionpapers 
Utrecht School of Economics

Tjalling C. Koopmans Research Institute

Discussion Paper Series 13-07

\title{
Importing, productivity and SMEs: firm-level evidence from the Netherlands Marcel van den Berg \\ Utrecht School of Economics Utrecht University
}

June 2013

\begin{abstract}
Constructing a comprehensive data set covering Dutch firms over the years 2002-2008 I am the first to investigate the relationship between trade status, firm size and firm-level productivity in the Netherlands, thereby focusing particularly on small and medium sized enterprises (SMEs). The empirical evidence can be summarized in four stylized facts. The productivity ranking by trade status of Dutch manufacturing firms in increasing order of productivity is: non-traders, importers, exporters and two-way traders. Firm size and being controlled by a company located abroad are positively associated with firm-level productivity. The results point in the direction of self-selection of more productive manufacturing firms into importing, particularly for firms that did not trade altogether prior to the import start and for build-up periods of two and three years towards the import start. I do not find evidence that firms become more productive after an import start because of learning effects. I find considerable heterogeneity in the productivity premia of trade along the firm size distribution. The results suggest that exporting is more complex than sourcing inputs internationally for small firms relative to larger firms.
\end{abstract}

Keywords: Micro data, firm heterogeneity, imports, exports, productivity, the Netherlands.

JEL classification: D22, F14, F23.

\section{Acknowledgements}

This study is funded by the Ministry of Economic Affairs and the Ministry of Foreign Affairs of the Netherlands. I am grateful to Statistics Netherlands for providing me with the data underlying the analysis. I thank Marjolijn Jaarsma for her invaluable support in my comprehension of the various data sets. I also thank Charles van Marrewijk, Peter van Bergeijk, Saara Tamminen, Emre Akgündüz, Fabienne Fortanier, René Bongard, Oscar Lemmers, Martin Luppes, Selwyn Moons, Bastiaan Rooijakkers and participants at the 2012 annual conference of the European Trade Study Group in Leuven, Belgium, for valuable feedback and comments. Any remaining errors are my own. 


\section{Introduction}

Since the mid-1990s a stream of papers has been published on the different nature of firms that are internationally competing and firms that solely serve domestic markets. The surge in research on this topic was spurred by the seminal work of Bernard et al. (1995), Roberts and Tybout (1997) and Melitz (2003). An impressive body of literature has presented compelling evidence that firms engaging in international trade are larger, more productive, more capital intensive, pay higher wages, invest more in $R \& D$ and have a higher probability of survival than firms that focus primarily on domestic markets (see Greenaway and Kneller (2007a), Wagner (2007) and Wagner (2012) for a survey of the empirical evidence). However, until recently most attention was directed towards the relationship between export status and firm performance, while the impact of importing on firm performance has been investigated considerably less frequently, a point also stressed by Wagner (2012).

I add to the literature in several ways. First, I test whether importers outperform non-importers as the empirical evidence from previous studies suggests (see section 2). Second, I investigate the direction of causality between import status and productivity by testing the self-selection and learningby-doing hypotheses empirically, utilizing propensity score matching to test the latter. The results are summarized in four stylized facts. This paper marks the first effort to analyze firm heterogeneity regarding import status and firm performance employing Dutch firm-level data. ${ }^{1}$ The importance of this is stressed by Wagner (2011) who recommends researchers to "Recognize the important role of scientific replication studies that re-examine ideas from published research using different data sets from different countries and periods". Third, I investigate the relationship between firm size and productivity premia of importing along the full firm size distribution, in particular including small firms (1-5 fte). This is a sizable group frequently neglected in the firm heterogeneity literature, which has largely been focusing on medium sized and large firms thus far. Fourth, I account for differences between goods importing manufacturing firms, wholesale and retail traders and goods importing service providers in the analysis.

The paper is organized as follows. Section 2 provides a brief discussion of the empirical literature with respect to the relationship between import status and firm performance. Section 3 introduces the data employed in the empirical analysis, which is provided in section 4 . Section 5 concludes and

\footnotetext{
${ }^{1}$ See Kox and Rojas-Romagosa (2010) for an empirical analysis of the relationship between export participation and productivity using Dutch firm-level data.
} 
provides some directions for further research.

\section{Firm heterogeneity and imports}

The literature distinguishes several mechanisms through which importing and firm-level productivity could be causally related. Firms can raise productivity by importing R\&D intensive intermediate inputs from the technological frontier. Coe and Helpman (1995) and Coe et al. (1997) show empirically that productivity gains from R\&D are indeed not only considerable in the source country, but that the benefits are also reaped by importing economies, both developed and less developed. Lööf and Andersson (2010) argue that global specialization plays a key role in enhancing firm productivity, since importing enables firms to utilize inputs from the technological frontier. Acharya and Keller (2009) present evidence suggesting that importing is an important vehicle for technology transfers between countries, while Acharya and Keller (2008) show that trade liberalization induces technological learning and thereby raises domestic productivity if it affects the imports of advanced technologies. This enables specialization and the focusing of resources on activities in which firms excel. Moreover, importing might offer firms the possibility to purchase intermediate inputs at lower cost. The wider variety of intermediate inputs that becomes available through importing, amongst which higher quality inputs, can increase firm-level productivity, if imported and domestic inputs are imperfect substitutes. Manova and Zhang (2012) show empirically that firms vary the quality of their products across export destinations by using inputs of differing quality. In addition, importing firms may benefit from spill-over effects and increase productivity by learning from foreign suppliers. This combination of learning and variety effects is also referred to as the complementarity aspect of importing (Halpern et al., 2009). Finally, importing final goods increases competition on domestic markets, which forces domestic producers, regardless of their trading status, to operate more efficiently and thus become more productive (Amiti and Konings, 2007).

Firm level evidence suggests that firms importing inputs are indeed more productive than firms that source inputs solely domestically. However, the direction of causality is less well understood. Vogel and Wagner (2010) employ a panel data set of German manufacturing firms and perform a propensity score matching procedure to investigate the direction of causality between productivity and imports. They do not find convincing evidence for the learning-by-importing hypothesis. However, their results do indicate that future importers are already more productive than continuing non-importers 
three years prior to import start. This points to self-selection of more productive firms into foreign supply markets. These findings are largely congruent with related studies by Kasahara and Lapham (2008), Muûls and Pisu (2009), Eriksson et al. (2009), and Andersson et al. (2008). Evidence supporting the learning-by-importing hypothesis is presented by Lööf and Andersson (2010) and Hagemejer and Kolasa (2011).

A few general conclusions can be taken from the preceding discussion:

1. Importers tend to be more productive and perform better in general than non-traders.

2. Two-way traders are consistently considered to be among the most productive firms.

3. The evidence regarding the productivity ordering of sole importers and sole exporters is less conclusive.

4. The evidence pointing to self-selection into importing is quite compelling, indicating that firms need to have a certain threshold level of productivity in order to be able to bear the costs associated with an import start.

5. There is little evidence supporting the learning-by-importing hypothesis.

\section{Data and productivity estimation}

For the empirical analysis I merge information from three main Dutch data sources: the General Business Register (GBR), the Baseline Database and the International Trade Database, all provided by Statistics Netherlands, into a panel data set covering the years 2002 to 2008. The data from the three different sources are merged using an unique identification number which is assigned by Statistics Netherlands to each individual firm in the General Business Register. The merging procedure described in this section is graphically depicted in figure 1 .

The GBR is, in principle, exhaustive in the sense that it contains information about every firm in the Netherlands including a set of basic firm characteristics such as the number of employees in fulltime equivalents, the sector in which the firm operates according to the internationally standardized ISIC Rev. 3.1 sector classification ${ }^{2}$, the legal type of the firm and some general address information. The GBR forms the starting point for the accumulation of the panel. I take from a separate but related database information concerning the ultimate controlling institution of the firm, indicating whether

\footnotetext{
${ }^{2}$ The ISIC Rev. 3.1 sector classification mirrors the SBI'93 2-digit classification employed by Statistics Netherlands
} 
the ultimate controlling owner of the Dutch firm is located abroad.

Figure 1: Graphical representation of the merging steps towards a panel data set

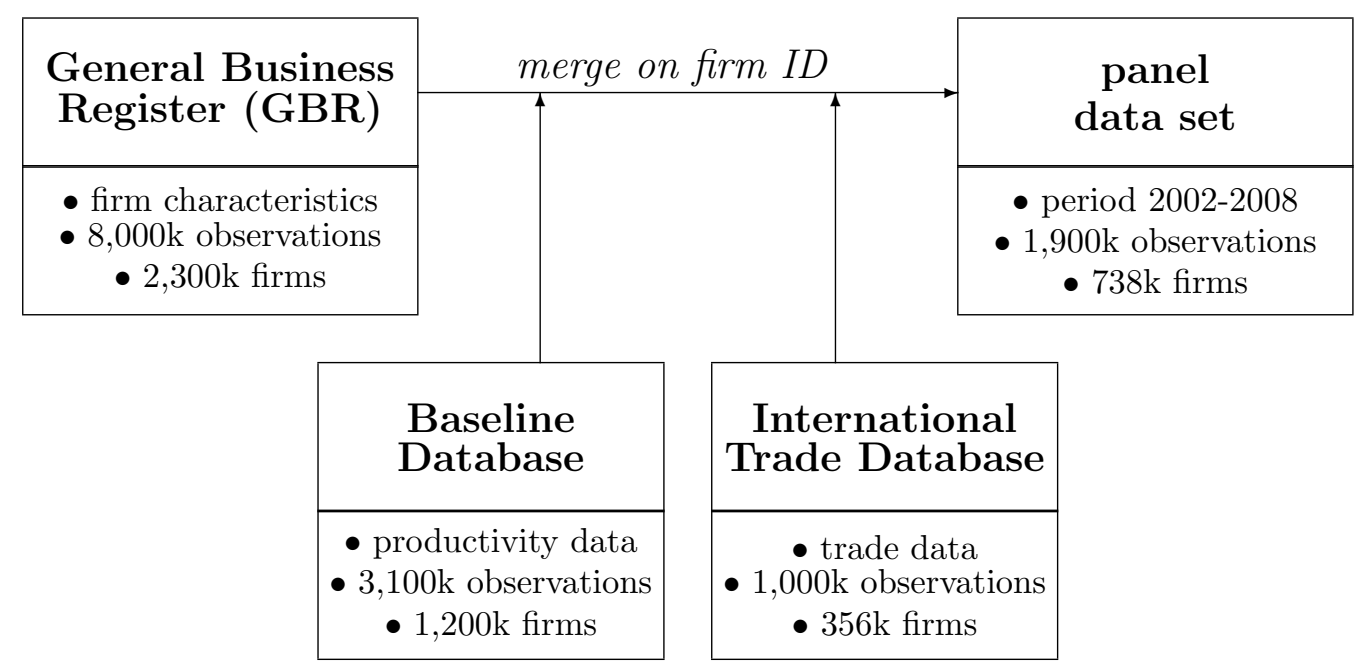

Data related to productivity measurement come from Baseline. This database contains a wealth of financial information collected from both corporate tax declarations and income tax declarations. However, corporate tax declarations are registered on Value Added Tax (VAT) numbers, which then need to be connected to the business identification numbers used by Statistics Netherlands. This match is only allowed when the connection is absolutely certain. Since firm structures tend to get more complex with increasing firm size, the success rate of the matching procedure decreases accordingly. Moreover, the Baseline data cover income tax statements of entrepreneurs only since 2006, the years 2002-2005 contain only data from corporate tax declarations. This implies that the number of observations in the panel increases from about 100,000 to roughly 500,000 annually and the average firm size in the panel drops once income tax information is included. The information taken from the Baseline database is modified to fit the widely used KLEMSframework, and contains information about gross output, value added and the value of capital, labor and intermediate inputs. ${ }^{3}$ The data regarding input used and output produced are deflated using separate sector level price indices for gross output, value added, labor, capital and intermediate inputs.

\footnotetext{
${ }^{3}$ The KLEMS-framework is an analytical framework in which data regarding input and output at the level of individual firms and industries are employed for growth and productivity analysis. One of the strengths of the KLEMS-framework is the international harmonization of the key concepts and methodologies.
} 
In the next step I merge the trade data to the GBR. Trade data were taken from the International Trade database and include information on all imports and exports of goods by Dutch firms. ${ }^{4}$ Since I only consider observations for which productivity information is available, I incur a loss of coverage mainly on account of a relatively small number of large firms. However, the merging strategy adopted aims at maximizing the number of trading firms in the panel rather than the trade value. ${ }^{5}$ In addition, the key focus of this paper is small and medium sized firms (SMEs), and trading patterns are likely to be more pronounced among small traders.

After a preliminary investigation of the data I eliminate micro firms (less than one fulltime equivalent), since these turn out to be difficult to measure consistently. I also eliminate implausible observations with zero or negative output or exports exceeding gross output and I eliminate two sectors with five observations or less. ${ }^{6}$ This procedure results in an unbalanced panel data set containing a total of 1,9 million observations of 738,000 unique firms spanning a period of seven years (2002-2008).

I calculate two different measures of productivity. Labor productivity (LP) is computed as value added per employee deflated using a sector specific price index. I estimate total factor productivity (TFP) by adopting the procedure proposed by Levinsohn and Petrin (2003). ${ }^{7}$ I employ information on trade values to construct a series of dummy variables, indicating whether the firm only exports, only imports, does both (two-way trade) or does neither (non-trader). Table 1 shows that over 70 percent of the firms in the panel do not trade internationally. ${ }^{8}$ Once the income tax information is included from 2006 onwards, this percentage rises to over 80 percent.

Table 2 shows the distribution of trade status over firm size categories. The fraction of non-traders decreases gradually with increasing firm size, although still 29 percent of the largest firms does not trade internationally. Especially two-way trading increases dramatically with firm size to over half of the largest firms engaging in both imports and exports. The fraction of

\footnotetext{
${ }^{4}$ The total value of intra-EU imports and exports is recorded by the Dutch Tax Authority. Extra-EU trade is recorded by the Customs Authority. Note that apart from the import value I do not have information as to whether it concerns imports of capital goods, intermediate inputs or final goods.

${ }^{5}$ The coverage of aggregate imports and exports in the panel is roughly 20 to 25 percent of the value of Dutch imports and 15 to 20 percent of the value of exports. As noted, this is mostly on account of an underrepresentation of large firms.

${ }^{6}$ These two sectors are 'Collection, purification and distribution of water' and 'Activities of private households as employers of domestic staff'.

${ }^{7}$ See Van den Berg (2013) for further details regarding the estimation procedure.

${ }^{8}$ The fraction of non-trading firms in the Dutch economy in total is about $80-85$ percent (CBS, 2010).
} 
firms only importing also increases with firm size, albeit to a lesser extent.

Table 1: Trade status of Dutch firms by year (\%)

\begin{tabular}{lrrrrr}
\hline & $\begin{array}{r}\text { non- } \\
\text { trading }\end{array}$ & $\begin{array}{r}\text { only } \\
\text { exports }\end{array}$ & $\begin{array}{r}\text { only } \\
\text { imports }\end{array}$ & $\begin{array}{r}\text { two-way } \\
\text { trading }\end{array}$ & total \\
\hline 2002 & 70.9 & 3.9 & 9.6 & 15.6 & 105,341 \\
2003 & 70.2 & 3.8 & 10.2 & 15.8 & 106,389 \\
2004 & 70.4 & 3.8 & 10.2 & 15.7 & 107,587 \\
2005 & 70.7 & 3.6 & 10.3 & 15.4 & 111,257 \\
\hline 2006 & 86.0 & 1.7 & $7 . \overline{2}$ & 5.2 & 466,107 \\
2007 & 84.3 & 1.9 & 8.2 & 5.6 & 486,965 \\
2008 & 81.4 & 2.4 & 10.1 & 6.1 & 559,504 \\
\hline total & $1,570,081$ & 46,776 & 173,467 & 152,826 & $1,943,150$ \\
\hline
\end{tabular}

Table 2: Trade status of Dutch firms by firm size (\%)

\begin{tabular}{lrrrrr}
\hline & $\begin{array}{r}\text { non- } \\
\text { trading }\end{array}$ & $\begin{array}{r}\text { only } \\
\text { exports }\end{array}$ & $\begin{array}{r}\text { only } \\
\text { imports }\end{array}$ & $\begin{array}{r}\text { two-way } \\
\text { trading }\end{array}$ & total \\
\hline fte $<5$ & 85.5 & 2.1 & 7.9 & 4.5 & $1,545,683$ \\
$5<=\mathrm{fte}<10$ & 67.3 & 3.6 & 13.4 & 15.7 & 191,142 \\
$10<=\mathrm{fte}<20$ & 61.9 & 3.9 & 12.6 & 21.6 & 113,513 \\
$20<=\mathrm{fte}<50$ & 54.4 & 3.7 & 13.1 & 28.8 & 64,573 \\
$50<=\mathrm{fte}<100$ & 47.8 & 3.3 & 13.7 & 35.2 & 15,382 \\
$100<=\mathrm{fte}<250$ & 39.8 & 2.0 & 14.0 & 44.1 & 6,863 \\
$\mathrm{fte}>250$ & 28.9 & 1.8 & 16.7 & 52.6 & 2,359 \\
\hline total & $1,566,728$ & 46,715 & 173,348 & 152,724 & $1,939,515$ \\
\hline
\end{tabular}

\section{Empirical findings}

\subsection{Do importers perform better?}

I start by establishing some stylized facts. Figure 2 shows that, in line with the literature reviewed in section 2, firms that only serve domestic markets are on average the least productive. ${ }^{9}$

The figure illustrates that the productivity distribution of non-traders is located left of the distributions of trading firms, namely exporters, importers and two-way traders, in that order, from left to right. The results of a series

\footnotetext{
${ }^{9}$ The top and bottom $1 \%$ of the observations along the relevant productivity distribution are excluded throughout this section, in order to eliminate implausible observations due to measurement errors, which I am unable to further investigate due to confidentiality considerations.
} 
of two-sided Kolmogorov-Smirnov tests for both total factor productivity and labor productivity are significant in all cases, indicating that the productivity distributions of the four groups divided by trade status do indeed differ. ${ }^{10}$

Figure 2: Firm-level productivity distribution by trade status (2002-2008)

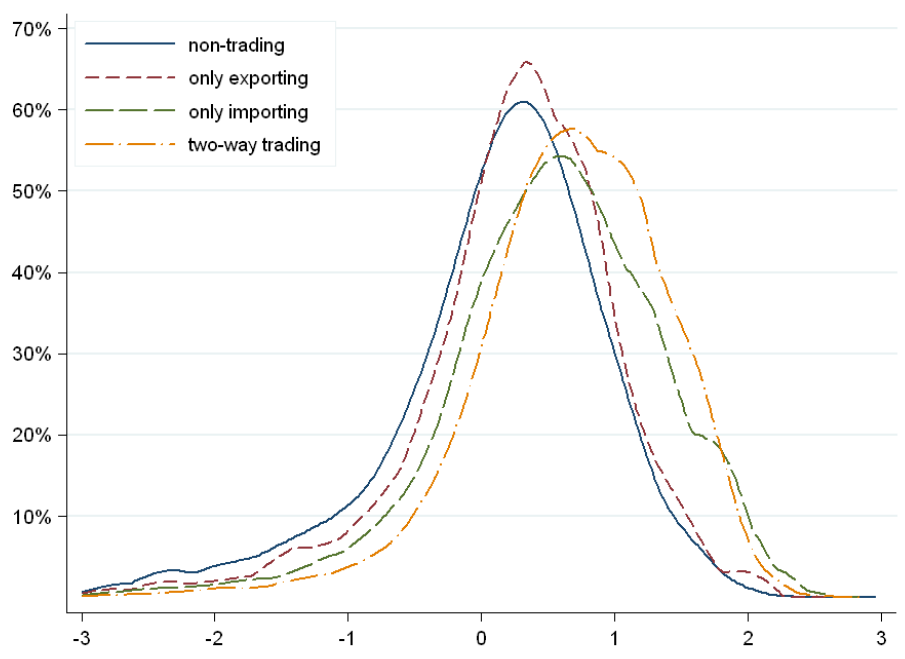

Notes: Following ?, the horizontal axis represents firm-level log of total factor productivity scaled by subtracting the annual median productivity of the firm's 2-digit sector. The vertical axis represents the density of firms at that particular productivity level, weighted by firm size in terms of employment.

The next step in the empirical analysis consists of estimating the trader premia, that is, the productivity difference between non-traders and traders that can be attributed to the differing trade status. In order to do so, I estimate the following empirical model:

$$
\begin{array}{r}
\ln \left(\operatorname{prod}_{i t}\right)=\alpha+\beta_{1} \text { importer }_{i t}+\beta_{2} \text { exporter }_{i t}+\beta_{3} \text { twowaytrader }_{i t} \\
+\beta_{4} \text { firmsize }_{i t}+\beta_{5} \text { foreigncontrolled }_{i t} \\
+\beta_{6} \text { year }_{t}+\beta_{7} \text { sector }_{i t}+\beta_{8} \text { region }_{i}+e_{i t}
\end{array}
$$

I estimate a pooled OLS-regression model employing the panel data concern-

\footnotetext{
${ }^{10}$ The results of the one-sided tests, without controlling for other firm characteristics, show that the productivity distribution of non-traders is being dominated by, respectively, sole importers, sole exporters and two-way traders. The ranking of sole exporters and sole importers is thus reversed compared to the productivity distributions depicted in figure 2 . See ? for a discussion of the Kolmogorov-Smirnov test. The results of the KolmogorovSmirnov tests are not reported for space considerations, detailed results are available from the author upon request.
} 
ing Dutch firms over the years 2002 to $2008 .^{11}$ In this model the subscript $i$ identifies individual firms and $t$ indexes the year. The dependent variable to be estimated $\left(\ln \left(\operatorname{prod}_{i t}\right)\right)$ is either the natural $\log$ of total factor productivity, denoted by $\operatorname{lnTFP} P_{i t}$, or the natural $\log$ of labor productivity, denoted by $\ln L P_{i t}$. Dummy variables regarding trade status, with nontrading firms as the reference group, are defined by importer $_{i t}$, exporter ${ }_{i t}$ and twowaytrader ${ }_{i t}{ }^{12}$ I also include a series of control variables: firm size in terms of employment in fulltime equivalents ( firmsize $_{i t}$ ), a dummy variable indicating whether the firm is controlled by a company located abroad foreigncontrolled $_{i t}$ ) and a full set of year $\left(\right.$ year $\left._{t}\right)$, 2-digit sector ( sector $_{i t}$ ) and region $\left(\right.$ region $\left._{i}\right)$ dummy variables. ${ }^{13}$ The region dummies identify the twelve Dutch provinces. ${ }^{14}$ Equation 1 is estimated in several ways. The data set contains firms from every 2-digit sector, and are thus not limited to particular manufacturing sectors. To gain an understanding of the underlying dynamics of the different sectors, I run each regression in four steps, one including all firms in the sample and three for separate subsets, one only including manufacturing sectors, one including wholesale and retail traders and one for typical (financial and public) service sectors. ${ }^{15}$ I run separate regressions for these main sectors, since the trade data only concern goods trade,

\footnotetext{
${ }^{11}$ It is customary in this strand of empirical literature that firm fixed effects models are estimated next to pooled OLS-models. However, the trade status of individual firms is generally relatively stable. The panel consists of more than 738,000 unique firms of which about 65,000 switch import status during the observed period, corresponding to about $9 \%$ of the population. This implies that the individual firm-specific intercept would capture the better part of the effect of trade status on firm-level productivity for those firms where the trade status does not change during the observed period. This implies that the estimated coefficient only reflects the effect of trade status on productivity for those firms where the trade status changed during the observed time period, leading to biased estimates of the trade premia.

${ }^{12} \mathrm{~A}$ firm is considered being an exporter resp. importer in a particular year if it reports an export resp. import value larger than zero in that year.

${ }^{13}$ The dummy variable indicating whether a firm is ultimately controlled by a foreign company is not derived from the underlying ownership structure, it indicates whether the controlling institution is effectively located abroad.

${ }^{14}$ The Dutch provinces align with the second level of regional aggregation of the Nomenclature of Units for Territorial Statistics (NUTS2) developed by the European Union.

${ }^{15}$ Manufacturing sectors correspond in the analysis to ISIC Rev. 3.1 sections A through I, excluding G. Wholesale and retail traders correspond to ISIC Rev. 3.1 section G and service sectors are defined as sections J to Q. The OECD and Eurostat recommend to define manufacturing as sections A through $\mathrm{F}$ and to include section $\mathrm{G}$ to $\mathrm{Q}$ in services. However, the main purpose of this division regards the output side, in terms of goods imports this division is less sensible, since a considerable part of goods trade takes place in trade and transport sectors it seems more appropriate to separate these sections from typical (financial and public) service sectors.
} 
and I have no information regarding trade in services, which could bias the estimations of trade premia of goods traders. Furthermore, I also distinguish firms active in wholesale and retail trading separately from manufacturing firms, since this group is likely to show different trading behavior.

Table 3: Total factor productivity premia of Dutch firms (pooled OLS, 2002-2008)

\begin{tabular}{lcccc}
\hline & & & wholesale and \\
& all firms & manufacturing & retail trade & services \\
\hline trade dummies & & & & \\
non-trader & reference & reference & reference & reference \\
only imports & $0.085^{* * *}$ & $0.065^{* * *}$ & $0.134^{* * *}$ & -0.007 \\
& $(33.40)$ & $(16.43)$ & $(36.86)$ & $(-1.09)$ \\
only exports & $0.125^{* * *}$ & $0.121^{* * *}$ & $0.213^{* * *}$ & $0.036^{* * *}$ \\
& $(27.65)$ & $(17.72)$ & $(28.31)$ & $(4.07)$ \\
two-way trader & $0.300^{* * *}$ & $0.202^{* * *}$ & $0.374^{* * *}$ & $0.147^{* * *}$ \\
& $(103.71)$ & $(45.63)$ & $(89.48)$ & $(18.99)$ \\
control variables & & & & \\
domestically controlled & reference & reference & reference & reference \\
foreign controlled & $0.302^{* * *}$ & $0.094^{* * *}$ & $0.329^{* * *}$ & $0.396^{* * *}$ \\
& $(38.32)$ & $(7.04)$ & $(30.07)$ & $(20.09)$ \\
firm size (fte, log) & $0.254^{* * *}$ & $0.249^{* * *}$ & $0.314^{* * *}$ & $0.224^{* * *}$ \\
& $(354.10)$ & $(256.67)$ & $(223.85)$ & $(160.25)$ \\
\hline No. of observations & $1,642,142$ & 583,987 & 446,037 & 612,121 \\
adj. $R^{2}$ & 0.167 & 0.217 & 0.176 & 0.140 \\
\hline \multicolumn{1}{c}{ Notes: All regressions include year, sector and region fixed effects. } & $t$ statistics in \\
parentheses. ${ }^{*} p<0.05,{ }^{* *} p<0.01,{ }^{* * *} p<0.001$ & &
\end{tabular}

Tables 3 and 4 report the estimation results of the baseline model using TFP and LP as productivity measures. The results are largely as expected and confirm the previously established productivity ordering by trade status. The trade premia are of considerable magnitude and statistically significant. Only importing firms are an estimated 8.5 percent more productive in terms of TFP and 18.3 percent in terms of labor productivity. The difference between the estimated coefficients of the distinguished trade statuses is statistically significant in the models including all firms and the three separate subsets by main sector. This holds for both productivity measures. ${ }^{16}$ The coefficients of the control variables show the expected results. Firms controlled by a foreign owner consistently show a productivity premium and firm size significantly positively affects firm-level productivity. The geographic location of firms within the Netherlands significantly impacts upon firm-level productivity, indicating that economically peripheral regions seem to face a

\footnotetext{
${ }^{16}$ The only exception is the statistically insignificant difference between the estimated labor productivity premia of importing and exporting for service firms.
} 
productivity penalty compared to the economic center of the country. ${ }^{17}$

Stylized fact I: The estimated productivity premia of trading translate into the following ranking of firms by trade status:

$$
\text { non-trader }<\text { only imports }<\text { only exports }<\text { two-way trader }
$$

Stylized fact II: Firm size and being controlled by a company located abroad are positively associated with firm-level productivity.

Table 4: Labor productivity premia of Dutch firms (pooled OLS, 2002-2008)

\begin{tabular}{lcccc}
\hline & & \multicolumn{3}{c}{ wholesale and } \\
& all firms & manufacturing & retail trade & services \\
\hline trade dummies & & & & \\
non-trader & reference & reference & reference & reference \\
only imports & $0.183^{* * *}$ & $0.147^{* * *}$ & $0.227^{* * *}$ & $0.121^{* * *}$ \\
& $(64.33)$ & $(33.46)$ & $(55.35)$ & $(17.55)$ \\
only exports & $0.220^{* * *}$ & $0.204^{* * *}$ & $0.317^{* * *}$ & $0.126^{* * *}$ \\
& $(43.99)$ & $(26.98)$ & $(37.74)$ & $(13.11)$ \\
two-way trader & $0.442^{* * *}$ & $0.312^{* * *}$ & $0.515^{* * *}$ & $0.323^{* * *}$ \\
& $(137.92)$ & $(63.97)$ & $(110.95)$ & $(38.30)$ \\
control variables & & & & \\
domestically controlled & reference & reference & reference & reference \\
foreign controlled & $0.293^{* * *}$ & $0.120^{* * *}$ & $0.246^{* * *}$ & $0.425^{* * *}$ \\
& $(34.27)$ & $(8.59)$ & $(21.00)$ & $(19.49)$ \\
firm size (fte, log) & $0.104^{* * *}$ & $0.093^{* * *}$ & $0.191^{* * *}$ & $0.069^{* * *}$ \\
& $(128.22)$ & $(86.51)$ & $(120.27)$ & $(43.23)$ \\
\hline No. of observations & $1,746,625$ & 608,120 & 466,291 & 672,214 \\
adj. $R^{2}$ & 0.111 & 0.115 & 0.108 & 0.113 \\
\hline \multicolumn{1}{c}{ Notes: All regressions include year, sector and region fixed effects. } & $t$ statistics in \\
parentheses. ${ }^{*} p<0.05,{ }^{* *} p<0.01, * * *$ & $p<0.001$ & &
\end{tabular}

Splitting the panel into three parts for typical manufacturing, trading and service sectors does reveal some interesting patterns. Wholesale and retail traders show the highest productivity premium for both TFP and labor productivity of 13.4 resp. 22.7 percent, followed closely by manufacturers; 6.5 resp. 14.7 percent. In addition, I find a consistent productivity ordering for each subset, with two-way traders being the most productive, followed by sole exporters, sole importers and non-traders, in that order. The estimated productivity premia of goods trade for service sectors are considerably smaller. These results hold for both TFP and labor productivity estimates, although the effect is more pronounced for the TFP-estimations. ${ }^{18}$ It is difficult to hypothesize about the impact of separating service sectors. Including

\footnotetext{
${ }^{17}$ See table 9 in the appendix.

${ }^{18}$ The baseline TFP-model even returns an insignificant coefficient for goods importing service providers.
} 
service sectors in the full panel implies that firms that trade in services but do not engage in goods trade are considered a non-trader. This might reduce the estimated productivity premia of goods traders relative to non-traders. However, engaging in both goods and service trading could imply incurring higher fixed cost of trading, which would raise the threshold level of productivity required to make both goods and service trade profitable. This would increase the estimated productivity premium of goods traders relative to non-traders.

\subsection{Trade premia and firm size}

The results of the baseline models estimated in section 4.1 show that trade status, firm size and productivity are correlated. In this section I take the analysis one step further and investigate whether trade premia vary along the firm size distribution. ${ }^{19}$ I proceed in two steps. First, I add interaction terms between firm size and trade status to the baseline model. Second, to be able to identify possible nonlinearities in the relationship between productivity, trade status and firm size, I run the baseline model for each size class separately. ${ }^{20}$ I specifically focus attention on the smallest firm size classes in this section, since the coverage of these size groups in the panel is of good quality, while they have been largely ignored thus far in the empirical literature.

$$
\begin{array}{r}
\ln \left(\text { prod }_{i t}\right)=\alpha+\beta_{1} \text { importer }_{i t}+\beta_{2} \text { exporter }_{i t}+\beta_{3} \text { twowaytrader }_{i t} \\
+\beta_{4} \text { firmsize }_{i t} \times \text { tradestatus }_{i t}+\beta_{4} \text { firmsize }_{i t} \\
+\beta_{5} \text { foreigncontrolled }_{i t}+\beta_{6} \text { year }_{t}+\beta_{7} \text { sector }_{i t}+\beta_{8} \text { region }_{i}+e_{i t}
\end{array}
$$

The baseline model including interaction terms between firm size and trade status is given in equation 2. The trade status of firms is interacted with either the (natural logarithm) of firm size in terms of fulltime equivalents as a continuous variable or firm size by size class. The results of the former regression are shown in column (1) of table 10 in the appendix and indicate that the productivity premium of importing increases in firm size.

\footnotetext{
${ }^{19}$ To make sure that the firms under investigation do not differ fundamentally in terms of the underlying business operations I focus attention from this point onwards on manufacturing sectors.

${ }^{20}$ I only include size classes up to 250 employees in this section, thereby omitting the largest size class, containing firms with more than 250 employees, from the analysis, since I know that I do not observe a representative subset of large firms in the panel data set. Furthermore, robustness tests (estimation results available from the author on request) indicate that the estimated trade premia from the baseline model in section 4.1 are robust to the exclusion of the largest size class of firms from the analysis.
} 
Productivity premia of exporting and two-way trading decrease in firm size. This could indicate that the fixed cost associated with exporting is higher relative to importing for smaller firms, which raises the threshold level of productivity required for profitable exporting relative to importing. However, since interacting trade status with a continuous measure of firm size does not reveal possible nonlinearities I also run the model including size class dummies. The results, depicted in column (2) of table 10 show that productivity continuously increases in firm size. In addition, productivity premia of importing generally increase in firm size, although the coefficient turns insignificant for the largest size class. The interaction terms show that the productivity premium of exporting generally decreases in firm size, except for firms up to 250 employees. The picture emerging for two-way trading is mixed, although relative to the smallest firms the estimated premia for the larger size classes are consistently significant and negative.

Figure 3: Total factor productivity premia of Dutch manufacturing firms by size class (2002-2008)

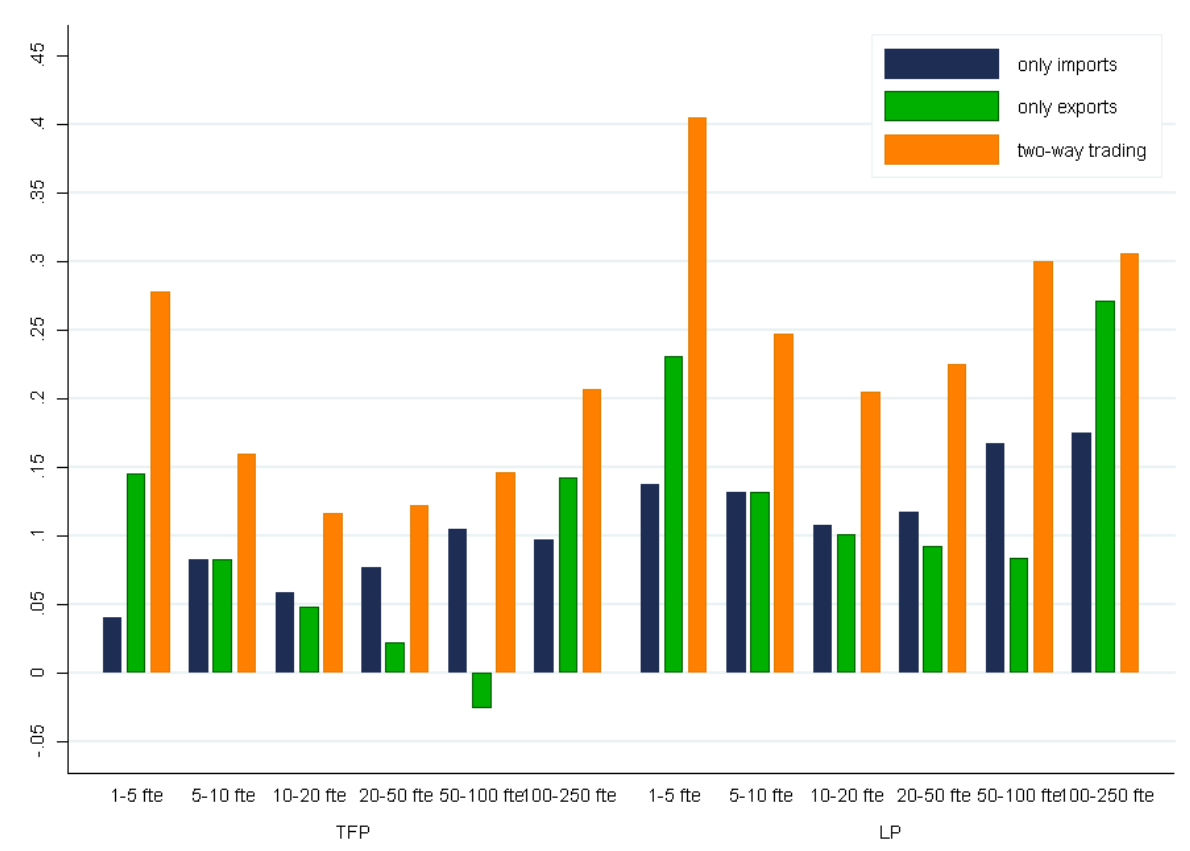

To allow for maximum flexibility in the estimation procedure I finally run the baseline model presented in equation 1 on the subset of manufacturing firms for the different firm size classes separately. The results regarding the estimated trade premia are graphically presented in figure 3. I consistently find evidence for the existence of a productivity premium for Dutch 
importers. Import premia are significant and positive for all size classes for both TFP and labor productivity. However, a clear picture does not emerge in terms of the magnitude of import premia for different size groups. The results show that firms with up to five employees return the smallest TFPpremium of importing of 4 percent and firms over 50 fte show the largest TFP-premium of importing, up to 10.5 percent. However, size classes in between do not show a steady increase of import premia. As for labor productivity I also find evidence indicating that firms over 50 employees experience the largest productivity premium. In addition, firms in the mid section of the firm size distribution, with 10 to 50 employees, return the smallest import premia, yielding an $U$-shaped import premium pattern by size class.

The TFP-premium for exporters decreases steadily in firm size, even turning insignificant for firms with more than 20 employees. Firms with up to 5 employees thus show the highest export premium with 14.5 percent. For labor productivity the picture is less clear. Export premia decrease in firm size, turning insignificant for firms over 50 employees, thus largely comparable with the findings for TFP. However, for firms with 100 to 250 employees the export premium turns significant again, with a considerable size of 27.1 percent. As for two-way trading I see a consistently $U$-shaped productivity premium pattern for both TFP and labor productivity, with the highest trade premium for firms up to 5 employees. These results suggest that in relative terms, compared to larger firms, employing export activities is more complex for small firms than engaging in international sourcing of inputs. This implies that a higher level of productivity is required for smaller firms in order to be able to successfully deal with the apparent complexity of export markets, hence the disappearing significance of exporter premia with increasing firm size, while import premia remain significant and positive throughout the complete firm size distribution. Furthermore, the adjusted $R^{2}$ is lower in the model specification regarding firms up to 5 employees compared to larger firms, indicating that for this size group there are unobserved, most likely firm specific, determinants of trading behavior which play a less prominent role in the decision process of larger firms. International orientation and experience of the working owner could be an example of a factor that impacts upon trade patterns among small firms without playing a major role in the decision process of larger firms.

\subsection{Direction of causality I: self-selection or not?}

In the previous section I presented empirical evidence that Dutch importers are more productive than non-traders. The next question to answer concerns the direction of causality: does the firm become an importer because it is 
more productive than its non-importing peer prior to the switching of trade status, or does it become more productive once it starts importing due to learning effects. In order words, do firms self-select into importing, learn by importing, or both?

In order to investigate the self-selection hypothesis I look at persisting productivity differences between import starters and continuing non-importers several years before the import start. Common in the literature is to evaluate productivity differences three years prior to the import start. The choice for this time horizon seems to be rather arbitrary. Roberts and Tybout (1997) show that the effect of past export experience depreciates in about two years, implying that firms with past export experience are no different from persistent non-exporters as soon as they have been out of export markets for more than two years, which could justify the choice for a time horizon of (at least) three years. To get a grasp of possible different productivity premia in the years leading up to an import start I consider time horizons of two, three and four years prior to the import start in the analysis.

In order to do so I compare two groups of import starters with their continuing non-importing peers; firms that start importing in year $t$ that did not trade in years $t$ - $T$ through $t-1$ and firms that start importing in year $t$ that exported at least once in years $t$ - $T$ through $t$-1, with $2 \leq T \leq 4$. The first group is compared to the group of firms that continued to be non-trader in year $t$, the latter is compared to firms that did not import, but exported at least once in years $t$ - $T$ through $t$-1. The panel, covering the years 2002-2008, allows me to identify three to five cohorts of import starters, depending on the time horizon. For each paired cohort I estimate a pooled OLS-regression model that is specified as follows:

$$
\begin{aligned}
& \ln \left(\operatorname{prod}_{i t-T}\right)=\alpha+\beta_{1} \text { importer }_{i t}+\beta_{2} \text { foreigncontrolled }_{i t-T} \\
& +\beta_{3} \text { firmsize }_{i t-T}+\beta_{4} \text { year }_{t}+\beta_{5} \text { sector }_{i t-T}+\beta_{6} \text { region }_{i}+e_{i t}
\end{aligned}
$$

Each variable in this model is defined in the same way as in equation 1, all explanatory variables are also lagged $T$ years, except for time-invariant variables and the dummy marking the import start. Table 5 shows the results for both total factor productivity and labor productivity and varying time horizons. ${ }^{21}$

The evidence regarding self-selection of manufacturing firms into import markets is mixed. However, all significant estimated coefficients on the importer dummy are positive. Especially for non-trading import starters the evidence pointing towards self-selection into importing is rather compelling,

\footnotetext{
${ }^{21}$ I only present the coefficient on the importer dummy for space considerations, the full estimation results are available from the author upon request.
} 
particularly considering a time horizon of three years. All but one of the cohorts for TFP and labor productivity return a significant estimate three years prior to import market entry of non-traders. The magnitude of the labor productivity difference between non-traders and import starters at $t$-3 is somewhat greater than the findings of Vogel and Wagner (2010) for Germany. The estimations suggest that labor productivity of import starters is 7.4 to 17.4 percent higher three years prior to the import start than that of continuing non-traders. For TFP the estimated premia are lower; 7.3 to 13.3 percent. Exporting import starters show less convincing self-selection behavior, although still more than half of the cohorts returns a significantly positive estimate. The results suggest that non-trading import starters are more productive two years prior to import start, particulary in terms of labor productivity. The evidence does not confirm this for import starters in possession of export experience. Finally, firms do not seem to be concerned with an impending import start four years prior to import market entry, considering the scarcity of significant premia for the four year time horizon.

The results thus point in the direction of self-selection of more productive manufacturing firms into importing, particularly for firms that did not trade altogether prior to the import start and for time horizons of two and three years. These results align with the findings of Roberts and Tybout (1997) in the sense that the less convincing evidence regarding the time horizon of two years could be at least partially explained by the fact that the group of continuing non-importers may contain firms that recently exited import markets, but did not fully depreciate the beneficial characteristics of being an importer yet.

Table 6 presents the results of the self-selection analysis for different size classes. ${ }^{22}$ The results should be interpreted with caution, since the numbers of observations for the different size classes, particularly the numbers of import starters, is relatively small. It is possible that no empirical evidence for significant productivity premia is found not because it does not exist but because the variation in the underlying data regarding the numbers of import starters is too small. However, all significant productivity premia are positive again.

\footnotetext{
${ }^{22}$ I only present the results for size classes up to 50 employees and for non-traders starting to import, since the number of observations for larger firm size groups and exporters starting to import is too small to infer any useful conclusions from.
} 
Table 5: Self-selection of Dutch manufacturing firms into goods import markets

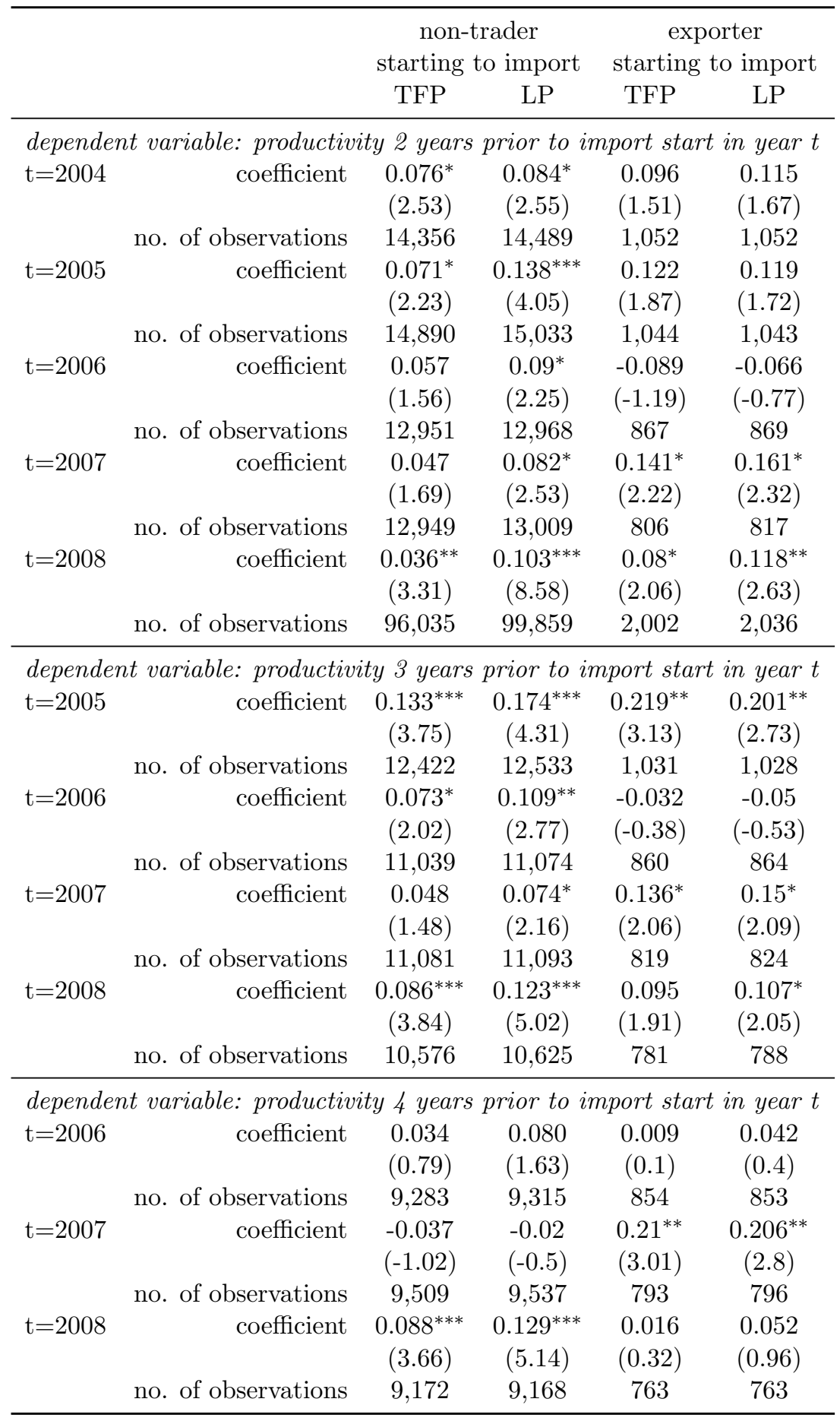

Notes: $t$ statistics in parentheses. ${ }^{*} p<0.05,{ }^{* *} p<0.01,{ }^{* * *} p<0.001$ 
Table 6: Self-selection of Dutch manufacturing firms by size class into goods import markets

\begin{tabular}{|c|c|c|c|c|c|c|c|c|c|}
\hline & & \multicolumn{2}{|c|}{$1-5 \mathrm{fte}$} & \multicolumn{2}{|c|}{$5-10 \mathrm{fte}$} & \multicolumn{2}{|c|}{$10-20 \mathrm{fte}$} & \multicolumn{2}{|c|}{$20-50 \mathrm{fte}$} \\
\hline & & TFP & LP & TFP & LP & TFP & LP & TFP & LP \\
\hline \multicolumn{10}{|c|}{ dependent variable: productivity 2 years prior to import start in year $t$} \\
\hline \multirow[t]{3}{*}{$t=2004$} & coefficient & 0.14 & $0.181^{*}$ & $0.093^{*}$ & 0.082 & 0.008 & & 0.107 & 0.105 \\
\hline & & $(1.87)$ & $(2.25)$ & $(2.03)$ & $(1.6)$ & $(0.16)$ & $(0.49)$ & $(1.66)$ & $(1.39)$ \\
\hline & no. of obs. & 5,373 & 5,448 & 3,619 & 3,652 & 3,071 & 3,093 & 1,886 & 1,886 \\
\hline \multirow[t]{3}{*}{$\mathrm{t}=2005$} & coefficient & 0.093 & $0.226^{* *}$ & 0.099 & $0.136^{*}$ & 0.02 & 0.06 & 0.052 & 0.091 \\
\hline & & $(1.26)$ & $(2.89)$ & $(1.75)$ & $(2.3)$ & $(0.39)$ & $(1.07)$ & $(0.97)$ & $(1.43)$ \\
\hline & no. of obs. & 5,679 & 5,772 & 3,734 & 3,76 & 3,183 & 3,195 & 1,882 & 1,885 \\
\hline \multirow[t]{3}{*}{$\mathrm{t}=2006$} & coefficient & 0.082 & 0.094 & 0.091 & $0.138^{*}$ & 0.013 & 0.053 & 0.033 & 0.1 \\
\hline & & (1.02) & (1.0 & $(1.49)$ & (1. & $(0.22)$ & $(0.7$ & $(0.39)$ & (1. \\
\hline & no. of obs. & 4,724 & 4,7 & 3,429 & & 2,891 & 2,9 & 1,605 & 1,6 \\
\hline \multirow[t]{3}{*}{$\mathrm{t}=2007$} & coefficient & 0.085 & 0.113 & 0.012 & 0.023 & 0.057 & $0.108^{*}$ & -0.071 & -0.02 \\
\hline & & $(1.45)$ & $(0.171)$ & $(0.23)$ & $(0.36)$ & $(1.37)$ & $(2.2)$ & $(-0.92)$ & $(-0.23)$ \\
\hline & no. of obs. & 4,789 & 4,800 & 3,457 & 3,483 & 2,864 & 2,874 & 1,541 & 1,551 \\
\hline \multirow[t]{3}{*}{$t=2008$} & coefficient & 0.027 & $0.102^{* * *}$ & 0.037 & $0.086^{* * *}$ & $0.082^{* * *}$ & $0.105^{* * *}$ & 0.035 & $0.097^{*}$ \\
\hline & & $(1.87)$ & $(6.45)$ & $(1.89)$ & $(4.15)$ & (3.81) & $(4.46)$ & $(0.99)$ & $(2.39)$ \\
\hline & no. of obs. & 81,310 & 85,060 & 8,429 & 8,484 & 4,282 & 4,293 & 1,699 & 1,705 \\
\hline \multicolumn{10}{|c|}{ dependent variable: productivity 3 years prior to import start in year $t$} \\
\hline \multirow[t]{3}{*}{$\mathrm{t}=2005$} & coefficient & $0.291^{* * *}$ & $0.349^{* * *}$ & 0.084 & $0.14^{*}$ & 0.033 & 0.064 & 0.016 & 0.05 \\
\hline & & $(3.7)$ & $(3.78)$ & $(1.34)$ & $(2.02)$ & $(0.51)$ & $(0.9)$ & $(0.24)$ & $(0.6$ \\
\hline & no. of obs. & 4,666 & 4,7 & 3,14 & & 2,689 & 2,7 & 1,607 & 1,6 \\
\hline \multirow[t]{3}{*}{$\mathrm{t}=2006$} & coefficient & 0.122 & $0.184^{*}$ & 0.055 & 0.076 & 0.086 & $0.141^{*}$ & 0.083 & 0.107 \\
\hline & & (1.37) & $(2.00)$ & $(0.88)$ & $(1.0$ & $(1.75)$ & & $(1.42)$ & $(1.56)$ \\
\hline & no. of obs. & 3,996 & 3,998 & 2,954 & 2,975 & 2,473 & 2,483 & 1,364 & 1,365 \\
\hline \multirow[t]{3}{*}{$t=2007$} & coefficient & 0.094 & 0.103 & -0.058 & -0.002 & 0.084 & $0.121^{*}$ & -0.057 & -0.019 \\
\hline & & $(1.35)$ & $(1.38)$ & $(-0.97)$ & $(-0.03)$ & $(1.96)$ & $(2.53)$ & $(-0.68)$ & $(-0.21)$ \\
\hline & no. of obs. & 4,067 & 4,050 & 2,944 & 2,964 & 2,466 & 2,474 & 1,358 & 1,359 \\
\hline \multirow{3}{*}{$\mathrm{t}=2008$} & coefficient & 0.092 & $0.136^{*}$ & $0.072^{*}$ & $0.094^{*}$ & $0.104^{* *}$ & $0.144^{* * *}$ & -0.012 & 0.037 \\
\hline & & $(1.62)$ & & & & & & & \\
\hline & no. of obs. & 3,918 & 3,926 & 2,867 & 2,891 & 2,326 & 2,333 & 1,230 & 1,238 \\
\hline \multicolumn{10}{|c|}{ dependent variable: productivity 4 years prior to import start in year $t$} \\
\hline \multirow[t]{3}{*}{$\mathrm{t}=2006$} & coefficient & 0.071 & 0.193 & 0.007 & 0.033 & 0.068 & $0.124^{*}$ & -0.008 & -0.043 \\
\hline & & $(0.66)$ & & & & & & & \\
\hline & no. of obs. & 3,308 & 3,307 & 2,502 & 2,517 & 2,104 & 2,117 & 1,164 & 1,167 \\
\hline \multirow[t]{3}{*}{$\mathrm{t}=2007$} & coefficient & -0.110 & -0.123 & 0.090 & -0.061 & 0.043 & 0.05 & -0.06 & 0.005 \\
\hline & & $(-1.21)$ & $(-1.15)$ & $(-1.51)$ & $(-0.82)$ & $(1.12)$ & $(1.11)$ & $(-0.61)$ & $(0.06)$ \\
\hline & no. of obs. & 3,469 & 3,470 & 2,544 & 2,562 & 2,129 & 2,136 & 1,156 & 1,157 \\
\hline \multirow[t]{3}{*}{$\mathrm{t}=2008$} & coefficient & 0.104 & $0.156^{*}$ & 0.068 & $0.101^{*}$ & 0.072 & $0.123^{* *}$ & 0.022 & 0.06 \\
\hline & & $(1.76)$ & & (1.62) & & $(1.96)$ & & $(0.42)$ & (1.17) \\
\hline & no. of obs. & 3,386 & 3,361 & 2,466 & 2,483 & 2,025 & 2,029 & 1,096 & 1,096 \\
\hline
\end{tabular}

Notes: $t$ statistics in parentheses. ${ }^{*} p<0.05,{ }^{* *} p<0.01,{ }^{* * *} p<0.001$

Particularly for firms with up to five employees the empirical evidence suggests that import starters incur a productivity premium three years prior to import market entry. Again I see that the empirical evidence is much thinner for shorter and particularly for longer time horizons. Moreover, for 
firms with 10 to 20 employees there is some evidence pointing towards selfselection into import markets, particularly in terms of labor productivity, whereas for larger firms there is hardly any evidence in favor of self-selection. Note that there is also considerable variation in the results between cohorts of different years. The 2008 cohort of import starters yields significant results for most of the 2 and 3 year time horizons and firms up till 20 employees, whereas the results for other years are much more diffuse. This is possibly due to the inclusion of data from income tax statements since 2006, which particularly increases the number of observations satisfying the constraints for the 2008 cohorts and a 2 year time horizon.

Stylized fact III: More productive manufacturing firms self-select into importing, particularly small firms that did not trade altogether prior to the import start and considering time horizons of two and three years.

\subsection{Direction of causality II: learning by importing?}

The next step is to establish whether import starters incur gains from learning by importing. Presenting evidence that firms starting to import from abroad show higher productivity growth than firms that keep sourcing domestically is not sufficient to conclude that firms learn from importing. After all, in section 4.3 I presented evidence suggesting that import starters do indeed outperform continuing non-traders in terms of productivity in the years prior to foreign market entry. If import starters do indeed outperform continuing non-traders already before starting to import, then there would be no valid reason to expect this difference to disappear after the import start, except for a situation where import starters would be catching up with nontraders, but the analysis thus far has shown that this is not the case. On the other hand, it is impossible to check whether import starters would have continuously performed better than non-importers if they also continued their non-importing status, since this scenario is simply unobserved.

A common way to deal with this issue is to adopt propensity score matching (Greenaway and Kneller, 2007b). The objective of this procedure is to construct the non-observed counterfactual by matching each treated firm to a firm from the control group based on similarity of firm characteristics before the treatment. In this particular application the treatment is the import start of the firm. The aim is to analyze whether these matched pairs of firms show diverging productivity growth paths after the import start. I investigate this issue over two time frames, following Vogel and Wagner (2010). The import starting firm could immediately incur a productivity increase because it can benefit from e.g. the availability of more variety, higher quality or cheaper 
inputs or better technology in its production process. Furthermore, the import starter could continuously learn from importing through e.g. knowledge spillovers from foreign trading partners or competitors and efficiency gains through international competitive pressure. Vogel and Wagner (2010) refer to the former effect as the static learning effect and to the latter as the dynamic learning effect.

I employ propensity score matching to investigate the persistence of both the static and the dynamic learning effects of importing. Firms starting to import in year $t$ are matched to a continuing non-importer from the control group based on similarity of a set of firm characteristics at $t-1$. These characteristics are employed in a probit model to estimate the probability of an import start at time $t$, the so-called propensity score. The estimated probit model is thus specified as follows:

$$
\begin{array}{r}
\text { importer }_{i t}= \\
+\beta_{3} \text { foreigncontrolled }_{i t-1}+\beta_{4} \text { firmsize }_{i t-1} \\
+\beta_{5} \text { sector }_{i t-1}+\beta_{6} \text { region }_{i}+e_{i t}
\end{array}
$$

The variables in this model are defined in the same way as in equation 1 , all explanatory variables are lagged one year, except for time-invariant variables and productivity growth, which is defined as the percentage change of productivity between $t$-2 and $t-1 .^{23}$

Firms from the import-starting cohort are then matched to a peer from the continuingly non-importing control group by minimizing the difference in individual propensity scores; this procedure is referred to as nearest neighbor propensity score matching. The only additional condition that needs to be satisfied is that both treated and matched untreated firms continuously stay in business throughout the period under investigation. In the final step the productivity growth paths of the matched pairs of import starters and continuing non-importers are compared. The static learning effect is evaluated by comparing productivity growth between $t-1$ and $t$ and between $t$ and $t+1$. The dynamic learning effect is evaluated by comparing productivity growth paths from $t+1$ to $t+2$ and from $t+2$ to $t+3$.

I find no evidence pointing towards the existence of a static learning effect for Dutch import starters in manufacturing sectors (see table 7 . For nontrading import starters the number of treated firms ranges from 220 to 280 per year and the estimated ATTs vary from -10.4 to +7.2 percent. The estimated average treatment effects on the treated (ATT) do not significantly differ from zero, considering the fact that zero lies well within the bootstrapped and

\footnotetext{
${ }^{23}$ The per annum top and bottom 5 percent of the relevant productivity growth distribution in the analysis are excluded from the analysis.
} 
bias-corrected 95 percent confidence intervals for all but two of the identified cohorts. This indicates that the productivity growth paths of non-trading import starters and continuing non-traders do not significantly differ. ${ }^{24}$ The number of observations regarding exporting import starters ranges from 50 to 90 a year, with an estimated ATT varying between -13.1 to +14.9 percent. For all of the estimated ATTs zero lies inside the constructed confidence intervals, indicating that the ATT does not significantly differ from zero at the 95 percent significance level.

Table 7: Static effect of learning by importing on Dutch manufacturers

\begin{tabular}{|c|c|c|c|c|c|c|c|}
\hline \multicolumn{2}{|c|}{$\begin{array}{c}\text { productivity growth } \\
\text { outcome measure }\end{array}$} & $\begin{array}{l}\text { no. of matched } \\
\text { treated firms }\end{array}$ & \multirow[t]{2}{*}{$\begin{array}{l}\text { mean of matched } \\
\text { treated }(\%)\end{array}$} & \multirow[t]{2}{*}{$\begin{array}{l}\text { mean of matched } \\
\text { control group (\%) }\end{array}$} & \multirow[t]{2}{*}{$\begin{array}{l}\mathrm{ATT} \\
(\%)\end{array}$} & \multicolumn{2}{|c|}{$\begin{array}{c}\text { bias-corrected } \\
95 \% \text { confidence interval }\end{array}$} \\
\hline \multicolumn{5}{|c|}{ non-trader starting to import in year $t$} & & & \\
\hline \multirow[t]{2}{*}{$\mathrm{t}=2007$} & $T F P_{-06-07}$ & 273 & 13.5 & 14.5 & -1.1 & -7.7 & 4.7 \\
\hline & $T F P_{-07-08}$ & 265 & 0.6 & -2.1 & 2.8 & -3.4 & 8.8 \\
\hline \multirow[t]{2}{*}{$\mathrm{t}=2007$} & $L P_{-06-07}$ & 284 & 9.0 & 11.2 & -2.3 & -11.1 & 6.1 \\
\hline & $L P_{-07-08}$ & 282 & 4.0 & 2.8 & 1.1 & -6.3 & 10.8 \\
\hline \multirow[t]{2}{*}{$t=2006$} & $T F P_{-05-06}$ & 238 & 13.1 & 13.9 & -0.8 & -9.6 & 5.9 \\
\hline & $T F P_{-06-07}$ & 230 & 12.3 & 10.7 & 1.6 & -6.0 & 9.7 \\
\hline \multirow[t]{2}{*}{$\mathrm{t}=2006$} & $L P_{-05-06}$ & 246 & 21.6 & 14.4 & 7.2 & -5.6 & 17.6 \\
\hline & $L P_{-06-07}$ & 243 & 4.3 & 14.7 & $-10.4^{*}$ & -22.3 & -4.4 \\
\hline \multirow[t]{2}{*}{$\mathrm{t}=2005$} & $T F P_{-04-05}$ & 229 & 9.8 & 2.6 & $7.2^{*}$ & 2.0 & 14.7 \\
\hline & $T F P_{-05-06}$ & 220 & 10.8 & 17.2 & -6.3 & -17.7 & 1.4 \\
\hline \multirow[t]{2}{*}{$t=2005$} & $L P_{-04-05}$ & 242 & 6.3 & 5.7 & 0.6 & -8.2 & 5.7 \\
\hline & $L P_{-05-06}$ & 239 & 8.7 & 17.8 & -9.1 & -22.2 & 2.7 \\
\hline \multicolumn{8}{|c|}{ exporter starting to import in year $t$} \\
\hline \multirow[t]{2}{*}{$\mathrm{t}=2007$} & $T F P_{-06-07}$ & 88 & 13.4 & 13.4 & 0.0 & -13.8 & 15.4 \\
\hline & $T F P_{-07-08}$ & 86 & -4.2 & 0.0 & -4.2 & -15.1 & 7.2 \\
\hline \multirow[t]{2}{*}{$\mathrm{t}=2007$} & $L P_{-06-07}$ & 95 & 10.7 & 16.9 & -6.2 & -20.8 & 12.7 \\
\hline & $L P_{-07-08}$ & 99 & -1.6 & -3.5 & 1.9 & -13.0 & 17.1 \\
\hline \multirow[t]{2}{*}{$t=2006$} & $T F P_{-05-06}$ & 59 & 21.1 & 15.4 & 5.7 & -9.5 & 25.2 \\
\hline & $T F P_{-06-07}$ & 59 & 25.3 & 10.4 & 14.9 & -1.6 & 30.5 \\
\hline \multirow[t]{2}{*}{$t=2006$} & $L P_{-05-06}$ & 63 & 29.5 & 14.8 & 14.7 & -1.4 & 40.0 \\
\hline & $L P_{-06-07}$ & 66 & 24.2 & 15.4 & 8.8 & -13.7 & 30.1 \\
\hline \multirow[t]{2}{*}{$t=2005$} & $T F P_{-04-05}$ & 49 & 10.9 & 9.1 & 1.8 & -11.1 & 15.6 \\
\hline & $T F P_{-05-06}$ & 49 & 12.0 & 25.1 & -13.1 & -34.1 & 3.5 \\
\hline \multirow[t]{2}{*}{$\mathrm{t}=2005$} & $L P_{-04-05}$ & 52 & 8.9 & 13.9 & -5.0 & -27.0 & 14.5 \\
\hline & $L P_{-05-06}$ & 53 & 10.7 & 21.9 & -11.2 & -37.2 & 12.7 \\
\hline
\end{tabular}

Notes: Nearest neighbor propensity score matching was done using Stata 11 and the psmatch2 package developed by Leuven and Sianesi (2003). The common support condition is imposed on the matching procedure, implying that treated firms with a propensity score higher than the maximum of the non-treated control group and lower than the minimum of the control group are taken off support and are not matched to a peer. The balancing property condition, requiring absence of statistically significant differences between the means of the matching characteristics of the firms in the treatment and the control group is fully satisfied in all but one instance. The bias-corrected $95 \%$ matching characteristics of the firms in the treatment and the control group is fully satisfied in al
confidence intervals are generated by bootstrapping the ATT with 1,000 replications. ${ }^{*} p<0.05$

Table 8 shows the results of the propensity score matching analysis of the dynamic learning by doing effect. Again I do not find compelling evidence for the existence of diverging productivity growth paths of import starters and continuing non-importers. I am able to identify about 100 nontrading import-starters per year and estimate ATTs ranging from -5.6 to

\footnotetext{
${ }^{24}$ I choose to present bootstrapped and bias-corrected confidence intervals in stead of bootstrapped $p$-values, since it is argued in the literature that the distributional assumptions underlying the $t$-test are systematically violated in this type of research.
} 
+5.8 percent, for all of which zero lies well within the accompanying confidence interval. Exporting importers yield about 30 observations per cohort and estimated ATTs between -30 and +15.7 percent, of which only the former significantly differs from zero. Note that the results regarding exporting import starters should be interpreted with caution. Due to the relatively small number of observations the mean treatment effects and the resulting ATTs are subject to considerable volatility.

Table 8: Dynamic effect of learning by importing on Dutch manufacturers

\begin{tabular}{|c|c|c|c|c|c|c|c|}
\hline & $\begin{array}{l}\text { productivity growth } \\
\text { outcome measure }\end{array}$ & $\begin{array}{l}\text { no. of matched } \\
\text { treated firms }\end{array}$ & $\begin{array}{l}\text { mean of matched } \\
\text { treated }(\%)\end{array}$ & $\begin{array}{l}\text { mean of matched } \\
\text { control group }(\%)\end{array}$ & $\begin{array}{l}\mathrm{ATT} \\
(\%)\end{array}$ & \multicolumn{2}{|c|}{$\begin{array}{l}\text { bias-corrected } \\
95 \% \text { confidence interval }\end{array}$} \\
\hline \multicolumn{8}{|c|}{ non-trader starting to import in year $t$} \\
\hline $\mathrm{t}=2006$ & $T F P_{07-08}$ & 100 & -5.0 & -3.6 & -1.4 & -9.4 & 9.0 \\
\hline $\mathrm{t}=2006$ & $L P_{07-08}$ & 108 & 1.0 & 1.0 & 0.0 & -11.1 & 15.0 \\
\hline $\mathrm{t}=2005$ & $T F P_{06-07}$ & 97 & 6.1 & 11.7 & -5.6 & -15.1 & 4.6 \\
\hline $\mathrm{t}=2005$ & TF $P_{07-08}$ & 81 & 3.7 & 2.1 & 1.7 & -9.8 & 14.3 \\
\hline $\mathrm{t}=2005$ & $L P_{06-07}$ & 110 & 1.6 & 1.9 & -0.3 & -13.7 & 14.7 \\
\hline $\mathrm{t}=2005$ & $L P_{07-08}$ & 89 & 7.8 & 2.0 & 5.8 & -10.7 & 20.7 \\
\hline \multicolumn{8}{|c|}{ exporter starting to import in year $t$} \\
\hline $\mathrm{t}=2006$ & $T F P_{07-08}$ & 29 & -20.9 & 9.1 & $-30^{*}$ & -55.7 & -5.3 \\
\hline$t=2006$ & $L P_{07-08}$ & 31 & -16.1 & -2.5 & -13.7 & -49.4 & 15.3 \\
\hline $\mathrm{t}=2005$ & $T F P_{06-07}$ & 23 & 25.2 & 9.5 & 15.7 & -7.6 & 46.9 \\
\hline $\mathrm{t}=2005$ & $T F P_{07-08}$ & 21 & -3.1 & -7.6 & 4.5 & -18.1 & 35.7 \\
\hline $\mathrm{t}=2005$ & $L P_{06-07}$ & 29 & 25.4 & 29.0 & -3.6 & -47.5 & 30.3 \\
\hline $\mathrm{t}=2005$ & $L P_{07-08}$ & 26 & 3.2 & 18.3 & -15.1 & -65.6 & 12.5 \\
\hline
\end{tabular}

Stylized fact IV: There is little evidence in favor of the learning by importing hypothesis for SMEs, both in the short run and in the longer run.

\section{Conclusion and discussion}

Constructing a comprehensive data set covering Dutch firms over the years 2002-2008 I am the first to investigate the relationship between trade status, firm size and firm-level productivity in the Netherlands. The empirical results are summarized in four stylized facts. Firms that import and do not export are more productive than non-traders, while firms that only export are more productive than firms that only import and two-way traders are the most productive group. In terms of firm size I find significant importer productivity premia for all firm size classes, but I do not find a clear pattern in the magnitude of the estimated premia by size group. The productivity premia of sole exporters decreases in firm size, even disappearing for the 
largest firm size classes, whereas two-way traders show a $U$-shaped productivity premium curve, with the highest premia estimated for firms at both ends of the firm size distribution. These results suggest that compared to larger firms, employing export activities is more complex for small firms than engaging in international sourcing of inputs. This implies that a higher level of productivity is required for smaller firms in order to be able to successfully deal with the apparent complexity of export markets, hence the disappearing significance of exporter premia with increasing firm size, while import premia remain significant and positive throughout the complete firm size distribution.

The findings regarding the direction of causality align with earlier research. The results of the empirical analysis point in the direction of selfselection of more productive manufacturing firms into importing, particularly for firms that did not trade altogether prior to the import start and for time horizons of two and three years. I do not find evidence supporting the hypothesis that firms become more productive after an import start because of learning effects; import starters do not show significantly different productivity growth paths in the years after the import start compared to continuing non-traders, both in the short and the longer run.

Although it is by now well-established that importers outperform nontraders in terms of productivity, the evidence regarding the mechanism driving these productivity differences is still quite scarce. Further research will hopefully fill this void and show whether the underlying mechanisms uncovered for Germany by Vogel and Wagner (2010) and the Netherlands by this study are found in other advanced and developing countries as well. In addition, an interesting direction for further research could be the unraveling of the exact mechanisms driving productivity differences between non-traders and importers and the underlying direction of causality by investigating whether importing different types of products from different source countries affects firm performance. 


\section{A Appendix}

Table 9: Productivity premia of Dutch firms: regional dummy variables (pooled OLS, 2002-2008)

\begin{tabular}{|c|c|c|c|c|}
\hline & all firms & manufacturing & $\begin{array}{l}\text { wholesale and } \\
\text { retail trade }\end{array}$ & services \\
\hline \multicolumn{5}{|c|}{ total factor productivity premia; table 3 cont. } \\
\hline Groningen & reference & reference & reference & reference \\
\hline Friesland & $\begin{array}{c}0.035^{* * *} \\
(6.14)\end{array}$ & $\begin{array}{c}0.029^{* * *} \\
(4.06)\end{array}$ & $\begin{array}{l}0.017 \\
(1.62)\end{array}$ & $\begin{array}{c}0.056^{* * *} \\
(4.55)\end{array}$ \\
\hline Drenthe & $\begin{array}{l}-0.011 \\
(-1.75)\end{array}$ & $\begin{array}{l}0.016^{*} \\
(1.99)\end{array}$ & $\begin{array}{l}-0.018 \\
(-1.54)\end{array}$ & $\begin{array}{c}-0.048^{* * *} \\
(-3.56)\end{array}$ \\
\hline Overijssel & $\begin{array}{c}0.077^{* * *} \\
(14.55)\end{array}$ & $\begin{array}{c}0.093^{* * *} \\
(13.76)\end{array}$ & $\begin{array}{c}0.044^{* * *} \\
(4.51)\end{array}$ & $\begin{array}{c}0.086^{* * *} \\
(7.66)\end{array}$ \\
\hline Flevoland & $\begin{array}{c}0.076^{* * *} \\
(11.06)\end{array}$ & $\begin{array}{c}0.078^{* * *} \\
(8.64)\end{array}$ & $\begin{array}{l}0.058^{* * *} \\
(4.42)\end{array}$ & $\begin{array}{c}0.085^{* * *} \\
(6.39)\end{array}$ \\
\hline Gelderland & $\begin{array}{c}0.123^{* * *} \\
(25.55)\end{array}$ & $\begin{array}{c}0.128^{* * *} \\
(20.55)\end{array}$ & $\begin{array}{c}0.090^{* * *} \\
(10.01)\end{array}$ & $\begin{array}{c}0.143^{* * *} \\
(14.30)\end{array}$ \\
\hline Utrecht & $\begin{array}{c}0.226^{* * *} \\
(44.38)\end{array}$ & $\begin{array}{c}0.187^{* * *} \\
(27.84)\end{array}$ & $\begin{array}{c}0.189^{* * *} \\
(19.66)\end{array}$ & $\begin{array}{c}0.273^{* * *} \\
(26.92)\end{array}$ \\
\hline Noord-Holland & $\begin{array}{c}0.165^{* * *} \\
(35.18)\end{array}$ & $\begin{array}{c}0.149^{* * *} \\
(24.57)\end{array}$ & $\begin{array}{c}0.141^{* * *} \\
(15.94)\end{array}$ & $\begin{array}{c}0.200^{* * *} \\
(20.69)\end{array}$ \\
\hline Zuid-Holland & $\begin{array}{l}0.204^{* * *} \\
(43.81)\end{array}$ & $\begin{array}{c}0.207^{* * *} \\
(34.40)\end{array}$ & $\begin{array}{c}0.166^{* * *} \\
(19.05)\end{array}$ & $\begin{array}{c}0.229^{* * *} \\
(23.76)\end{array}$ \\
\hline Zeeland & $\begin{array}{c}0.076^{* * *} \\
(11.75)\end{array}$ & $\begin{array}{c}0.116^{* * *} \\
(14.29)\end{array}$ & $\begin{array}{l}0.025^{*} \\
(2.02)\end{array}$ & $\begin{array}{c}0.052^{* * *} \\
(3.61)\end{array}$ \\
\hline Noord-Brabant & $\begin{array}{c}0.119^{* * *} \\
(25.20)\end{array}$ & $\begin{array}{c}0.150^{* * *} \\
(24.65)\end{array}$ & $\begin{array}{c}0.083^{* * *} \\
(9.37)\end{array}$ & $\begin{array}{c}0.116^{* * *} \\
(11.85)\end{array}$ \\
\hline Limburg & $\begin{array}{c}0.015^{* *} \\
(2.90)\end{array}$ & $\begin{array}{c}0.028^{* * *} \\
(4.06)\end{array}$ & $\begin{array}{l}-0.012 \\
(-1.25)\end{array}$ & $\begin{array}{l}0.025^{*} \\
(2.27)\end{array}$ \\
\hline \multicolumn{5}{|c|}{ labor productivity premia; table 4 cont. } \\
\hline Groningen & reference & reference & reference & reference \\
\hline Friesland & $\begin{array}{c}0.077^{* * *} \\
(12.28)\end{array}$ & $\begin{array}{c}0.069^{* * *} \\
(8.84)\end{array}$ & $\begin{array}{c}0.051^{* * *} \\
(4.26)\end{array}$ & $\begin{array}{c}0.112^{* * *} \\
(8.48)\end{array}$ \\
\hline Drenthe & $\begin{array}{l}0.001 \\
(0.11)\end{array}$ & $\begin{array}{c}0.032^{* * *} \\
(3.53)\end{array}$ & $\begin{array}{l}-0.002 \\
(-0.19)\end{array}$ & $\begin{array}{l}-0.033^{*} \\
(-2.29)\end{array}$ \\
\hline Overijssel & $\begin{array}{c}0.098^{* * *} \\
(16.72)\end{array}$ & $\begin{array}{c}0.116^{* * *} \\
(15.53)\end{array}$ & $\begin{array}{c}0.057^{* * *} \\
(5.20)\end{array}$ & $\begin{array}{l}0.118^{* * *} \\
(9.76)\end{array}$ \\
\hline Flevoland & $\begin{array}{c}0.085^{* * *} \\
(11.21)\end{array}$ & $\begin{array}{l}0.094^{* * *} \\
(9.49)\end{array}$ & $\begin{array}{c}0.045^{* *} \\
(3.09)\end{array}$ & $\begin{array}{l}0.104^{* * *} \\
(7.28)\end{array}$ \\
\hline Gelderland & $\begin{array}{c}0.141^{* * *} \\
(26.38)\end{array}$ & $\begin{array}{c}0.151^{* * *} \\
(22.00)\end{array}$ & $\begin{array}{c}0.101^{* * *} \\
(9.94)\end{array}$ & $\begin{array}{c}0.165^{* * *} \\
(15.32)\end{array}$ \\
\hline Utrecht & $\begin{array}{c}0.218^{* * *} \\
(38.67)\end{array}$ & $\begin{array}{c}0.182^{* * *} \\
(24.43)\end{array}$ & $\begin{array}{c}0.167^{* * *} \\
(15.40)\end{array}$ & $\begin{array}{c}0.270^{* * *} \\
(24.84)\end{array}$ \\
\hline Noord-Holland & $\begin{array}{c}0.141^{* * *} \\
(27.19)\end{array}$ & $\begin{array}{c}0.133^{* * *} \\
(19.85)\end{array}$ & $\begin{array}{c}0.101^{* * *} \\
(10.11)\end{array}$ & $\begin{array}{c}0.183^{* * *} \\
(17.72)\end{array}$ \\
\hline Zuid-Holland & $\begin{array}{c}0.182^{* * *} \\
(35.29)\end{array}$ & $\begin{array}{l}0.188^{* * *} \\
(28.30)\end{array}$ & $\begin{array}{c}0.134^{* * *} \\
(13.59)\end{array}$ & $\begin{array}{c}0.219^{* * *} \\
(21.25)\end{array}$ \\
\hline Zeeland & $\begin{array}{c}0.105^{* * *} \\
(14.60)\end{array}$ & $\begin{array}{c}0.153^{* * *} \\
(17.06)\end{array}$ & $\begin{array}{c}0.049^{* * *} \\
(3.56)\end{array}$ & $\begin{array}{c}0.088^{* * *} \\
(5.66)\end{array}$ \\
\hline Noord-Brabant & $\begin{array}{c}0.128^{* * *} \\
(24.43)\end{array}$ & $\begin{array}{c}0.162^{* * *} \\
(24.22)\end{array}$ & $\begin{array}{c}0.080^{* * *} \\
(8.07)\end{array}$ & $\begin{array}{c}0.135^{* * *} \\
(12.79)\end{array}$ \\
\hline Limburg & $\begin{array}{l}0.005 \\
(0.79)\end{array}$ & $\begin{array}{c}0.020^{* *} \\
(2.61)\end{array}$ & $\begin{array}{c}-0.037^{* * *} \\
(-3.41)\end{array}$ & $\begin{array}{c}0.039^{* * *} \\
(3.31)\end{array}$ \\
\hline
\end{tabular}


Table 10: Productivity premia of Dutch manufacturing firms (pooled OLS, 2002-2008)

\begin{tabular}{|c|c|c|c|c|}
\hline & (1) & & $(2)$ & \\
\hline \multicolumn{5}{|l|}{ trade dummies } \\
\hline non-trader & reference & & reference & \\
\hline only imports & $\begin{array}{c}0.037^{* * *} \\
(5.56)\end{array}$ & & $\begin{array}{c}0.080^{* * *} \\
(13.70)\end{array}$ & \\
\hline only exports & $\begin{array}{c}0.163^{* * *} \\
(13.07)\end{array}$ & & $\begin{array}{c}0.189^{* * *} \\
(17.53)\end{array}$ & \\
\hline two-way trader & $\begin{array}{c}0.326^{* * *} \\
(36.32)\end{array}$ & & $\begin{array}{c}0.374^{* * *} \\
(43.00)\end{array}$ & \\
\hline firm size (fte, log) & $\begin{array}{l}0.256^{* * *} \\
(241.74)\end{array}$ & & & \\
\hline $1-5 \mathrm{fte}$ & & & reference & \\
\hline $5-10 \mathrm{fte}$ & & & $\begin{array}{l}0.414^{* * *} \\
(139.07)\end{array}$ & \\
\hline $10-20 \mathrm{fte}$ & & & $\begin{array}{l}0.578^{* * *} \\
(168.50)\end{array}$ & \\
\hline $20-50 \mathrm{fte}$ & & & $\begin{array}{l}0.696^{* * *} \\
(146.90)\end{array}$ & \\
\hline $50-100 \mathrm{fte}$ & & & $\begin{array}{c}0.817^{* * *} \\
(73.91)\end{array}$ & \\
\hline $100-250 \mathrm{fte}$ & & & $\begin{array}{c}0.973^{* * *} \\
(47.63)\end{array}$ & \\
\hline only imports * firm size (fte, $\log )$ & $\begin{array}{c}0.017^{* * *} \\
(5.31)\end{array}$ & & & \\
\hline only exports * firm size (fte, log) & $\begin{array}{c}-0.030^{* * *} \\
(-5.42)\end{array}$ & & & \\
\hline two-way trading $*$ firm size $(\mathrm{fte}, \log )$ & $\begin{array}{c}-0.058^{* * *} \\
(-18.51)\end{array}$ & & & \\
\hline \multicolumn{5}{|c|}{ interaction terms size class (rows) * trade status (columns) } \\
\hline & & only imports & only exports & two-way trading \\
\hline $1-5$ fte & & reference & reference & reference \\
\hline $5-10 \mathrm{fte}$ & & $\begin{array}{c}0.032^{* * *} \\
(3.35)\end{array}$ & $\begin{array}{c}-0.080^{* * *} \\
(-4.70)\end{array}$ & $\begin{array}{c}-0.177^{* * *} \\
(-15.55)\end{array}$ \\
\hline $10-20 \mathrm{fte}$ & & $\begin{array}{l}0.003 \\
(0.34)\end{array}$ & $\begin{array}{c}-0.108^{* * *} \\
(-6.50)\end{array}$ & $\begin{array}{c}-0.223^{* * *} \\
(-20.52)\end{array}$ \\
\hline $20-50 \mathrm{fte}$ & & $\begin{array}{c}0.037^{* *} \\
(3.14)\end{array}$ & $\begin{array}{c}-0.117^{* * *} \\
(-6.22)\end{array}$ & $\begin{array}{c}-0.171^{* * *} \\
(-15.36)\end{array}$ \\
\hline $50-100 \mathrm{fte}$ & & $\begin{array}{c}0.053^{*} \\
(2.06)\end{array}$ & $\begin{array}{c}-0.145^{* * *} \\
(-3.43)\end{array}$ & $\begin{array}{c}-0.131^{* * *} \\
(-7.46)\end{array}$ \\
\hline $100-250 \mathrm{fte}$ & & $\begin{array}{l}0.032 \\
(0.74)\end{array}$ & $\begin{array}{l}-0.024 \\
(-0.29)\end{array}$ & $\begin{array}{c}-0.187^{* * *} \\
(-7.25)\end{array}$ \\
\hline \multicolumn{5}{|l|}{ control variables } \\
\hline domestically controlled & reference & & reference & \\
\hline foreign controlled & $\begin{array}{c}0.183^{* * *} \\
(13.10)\end{array}$ & & $\begin{array}{c}0.225^{* * *} \\
(15.79)\end{array}$ & \\
\hline No. of observations & 583,234 & & 583,234 & \\
\hline $\operatorname{adj} . R^{2}$ & 0.216 & & 0.201 & \\
\hline
\end{tabular}




\section{References}

Acharya, R., and W. Keller. 2008. Estimating the productivity selection and technology spillover effects of imports, NBER Working Paper Series Working Paper 14079, National Bureau of Economic Research.

Acharya, R. C., and W. Keller. 2009. Technology transfer through imports. Canadian Journal of Economics 42 (4): 1411-1448.

Amiti, M., and J. Konings. 2007. Trade liberalization, intermediate inputs, and productivity: Evidence from indonesia. The American Economic Review 97 (5): 1611-1638.

Andersson, M., H. Lööf, and S. Johansson. 2008. Productivity and international trade: Firm level evidence from a small open economy. Review of world economics 144 (4): 774-801.

Bernard, A. B., J. B. Jensen, and R. Z. Lawrence. 1995. Exporters, jobs, and wages in us manufacturing: 1976-1987. Brookings Papers on Economic Activity. Microeconomics 1995: 67-119.

CBS. 2010. Internationalisation monitor 2010, Technical report, Statistics Netherlands.

Coe, D. T., and E. Helpman. 1995. International r\&d spillovers. European Economic Review 39 (5): 859-887.

Coe, D. T., E. Helpman, and A. Hoffmaister. 1997. North-south r\&d spillovers. The Economic Journal 107 (440): 134-149.

Eriksson, T., V. Smeets, and F. Warzynski. 2009. Small open economy firms in international trade: Evidence from danish transactions-level data, Aarhus University Department of Economics Working Paper Series Working Paper 09-7, Aarhus University School of Business.

Greenaway, D., and R. Kneller. 2007a. Firm heterogeneity, exporting and foreign direct investment. The Economic Journal 117 (517): 134-161.

Greenaway, D., and R. Kneller. 2007b. Industry differences in the effect of export market entry: learning by exporting? Review of World Economics 143 (3): 416-432.

Hagemejer, J., and M. Kolasa. 2011. Internationalisation and economic performance of enterprises: Evidence from polish firm-level data. The World Economy 34 (1): 74-100. 
Halpern, L., M. Koren, and A. Szeidl. 2009. Imported inputs and productivity, Central European University Economics Working Paper Series Working Paper 3/2009, Central European University.

Kasahara, H., and B. Lapham. 2008. Productivity and the decision to import and export: Theory and evidence, CESifo Working Paper Series Working Paper No. 2240, CESifo.

Kox, H. L. M., and H. Rojas-Romagosa. 2010. Exports and productivity selection effects for dutch firms. De Economist 158 (3): 295-322.

Leuven, Edwin, and Barbara Sianesi. 2003. PSMATCH2: Stata module to perform full Mahalanobis and propensity score matching, common support graphing, and covariate imbalance testing. Statistical Software Components, Boston College Department of Economics. http://ideas.repec. org/c/boc/bocode/s432001.html.

Levinsohn, James, and Amil Petrin. 2003. Estimating production functions using inputs to control for unobservables. The Review of Economic Studies 70 (2): 317-341. http://www.jstor.org/stable/3648636.

Lööf, H., and M. Andersson. 2010. Imports, productivity and origin markets: The role of knowledge-intensive economies. The World Economy 33 (3): 458-481.

Manova, K., and Z. Zhang. 2012. Export prices across firms and destinations. The Quarterly Journal of Economics (forthcoming) forthcoming.

Melitz, M. J. 2003. The impact of trade on intra-industry reallocations and aggregate industry productivity. Econometrica 71 (6): 1695-1725.

Muûls, M., and M. Pisu. 2009. Imports and exports at the level of the firm: Evidence from belgium. The World Economy 32 (5): 692-734.

Roberts, M. J., and J. R. Tybout. 1997. The decision to export in colombia: an empirical model of entry with sunk costs. The American Economic Review 87 (4): 545-564.

Van den Berg, M. 2013. Imports, productivity and firm size: firm-level evidence from the netherlands. mimeo.

Vogel, A., and J. Wagner. 2010. Higher productivity in importing german manufacturing firms: self-selection, learning from importing, or both? Review of World Economics 145 (4): 641-665. 
Wagner, J. 2007. Exports and productivity: A survey of the evidence from firm-level data. World Economy 30 (1): 60-82.

Wagner, J. 2011. From estimation results to stylized facts twelve recommendations for empirical research in international activities of heterogeneous firms. De Economist 159 (4): 389-412. doi:10.1007/s10645-011-91674. http://dx.doi.org/10.1007/s10645-011-9167-4.

Wagner, J. 2012. International trade and firm performance: a survey of empirical studies since 2006. Review of World Economics 148: 235-267. 10.1007/s10290-011-0116-8. http://dx.doi.org/10.1007/s10290011-0116-8. 